IRA-International Journal of Management \&

Social Sciences

ISSN 2455-2267; Vol.08, Issue 03 (September 2017)

Pg. no. 227-231

Institute of Research Advances

http://research-advances.org/index.php/RAJMSS

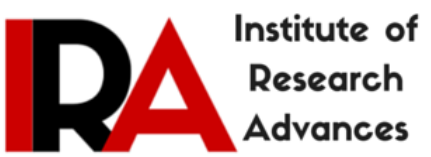

\title{
Implementation of Corporate Governance Norms in Select Indian Industries - A Case Study
}

\section{Dr. Sweta Modi}

Guest Faculty, Department of Management Studies, Faculty of Commerce and Management Studies, Jai Narain Vyas University, Jodhpur (Rajasthan), India.

Type of Review: Peer Reviewed.

DOI: http://dx.doi.org/10.21013/jmss.v8.n3.p1

\section{How to cite this paper:}

Modi, S. (2017). Implementation of Corporate Governance Norms in Select Indian Industries - A Case Study. IRA-International Journal of Management \& Social Sciences (ISSN 2455-2267), 8(3), 227-231. doi:http://dx.doi.org/10.21013/jmss.v8.n3.p1

(C) Institute of Research Advances.

\section{(cc) BY-NO}

This work is licensed under a Creative Commons Attribution-Non Commercial 4.0 International License subject to proper citation to the publication source of the work.

Disclaimer: The scholarly papers as reviewed and published by the Institute of Research Advances (IRA) are the views and opinions of their respective authors and are not the views or opinions of the IRA. The IRA disclaims of any harm or loss caused due to the published content to any party.

Institute of Research Advances is an institutional publisher member of Publishers Inter Linking Association Inc. (PILA-CrossRef), USA. The institute is an institutional signatory to the Budapest Open Access Initiative, Hungary advocating the open access of scientific and scholarly knowledge. The Institute is a registered content provider under Open Access Initiative Protocol for Metadata Harvesting (OAI-PMH).

The journal is indexed \& included in WorldCat Discovery Service (USA), CrossRef Metadata Search (USA), WorldCat (USA), OCLC (USA), Open J-Gate (India), EZB (Germany) Scilit (Switzerland), Airiti (China), Bielefeld Academic Search Engine (BASE) of Bielefeld University, Germany, PKP Index of Simon Fraser University, Canada. 


\begin{abstract}
This paper deals with the analysis of the implementation of corporate governance norms in the Indian industries. The analysis has been done for the sample companies falling into different categories of industry, in regard to the corporate governance reporting practices during the period of study. In the study it has been observed that the implementation of the corporate governance principles in the system and their reporting in the annual reports has been gradually and slowly incarnated into the corporate conscience to exude transparency, openness and accountability. The study in this period has covered compliance of the codes of corporate governance practices.
\end{abstract}

Keywords: Corporate Governance, Corporate Social Responsibility, LPG Process, Board of Directors, Clause 49 Listing Agreements.

\title{
Introduction
}

This article deals with the analysis of the implementation of corporate governance norms in the Indian industries. The main objective behind the corporate governance is to protect long-term shareholder value along with the other stakeholders. Corporate governance is a very wide term, which covers a wide range of activities that relate to the way business organization is directed and governed. It deals with the policies and practices that directly impact on the organizations performance, stewardship and its capacity to be accountable to its various stakeholders.

\section{Objective}

The present paper makes an attempt to examine the implementation of corporate governance reporting practices in the annual reports of the sample companies during the study period.

\section{Hypotheses}

This research paper develops the following null hypotheses for study.

Ho1 : $\quad$ The corporate governance reporting has not been predominantly followed in all Indian companies irrespective of nature, size and age.

Ho2 : There is no significant difference between the corporate governance reporting practices found in the annual reports of the Indian Companies.

\section{Sample Size}

During the first phase of meeting the initial objective of the study, i.e. the implementation of corporate governance reporting in the respective corporate annual reports, only 50 companies from 10 industries with a listing status either in BSE or in NSE have been found to follow the corporate governance reporting practices.

\section{Sample Source}

The data have been obtained from the database package PROWESS, of the CMIE, a Mumbai - based research firm. The other sources for the relevant study are: Notice of annual general meeting, Director's report, Auditor's report, the websites of the respective sample companies.

\section{Period of Study}

The study has covered a period of 3 years starting from 2013-14 to 2015-16. During the above period the Indian corporate sector has faced numerous world-wide issues and developments and in this reforms era, the gradual demand for raising standards and ethics in the form of corporate governance practices though various guidelines and recommendations were sprouting from the ground level. The study in this period has covered compliance of the codes of corporate governance practices. 


\section{Industry Analysis}

The inter-industry analysis has been carried out for the sample companies during the period of study. There are specific leaders who have understood the tenets of good governance and have consistently followed the reporting of the corporate governance practices as per the structure of Indian laws and regulations.

\section{Inter-industry Analysis}

In an attempt to make the inter-industry comparison, all the 50 sample companies have been categorized into 10 sub-group and through the perusal of the annual reports of the said companies, the results as revealed were distinctly grouped into three types as shown in Table 1.

Table 1

Group-wise Corporate Governance Reporting Results

\begin{tabular}{cccc}
\hline Group & No. of Companies & No. of Industries & Percentage of Companies \\
\hline I & 10 & 3 & $20 \%$ \\
II & 30 & 5 & $60 \%$ \\
III & 10 & 2 & $20 \%$ \\
& 50 & & \\
\hline
\end{tabular}

\section{Findings}

Group I: Industries reporting on corporate governance practices ahead of the imposition of regulatory norms

This group includes companies from those various industries which have been following the corporate governance practices and also reporting about the same in their annual reports as required by the Indian regulatory system. During the initial phase of study, only three industries out of the ten industries' group comprising of ten companies have been consistently following the practices of corporate governance norms and disclosing it through their annual reports, even before they were sought for strict implementation. They are from Automobiles, Computer Software, Oil \& Gas, Pharmaceuticals, Fast Moving Consumer Goods, Iron and steel, Banking \& Financial Services and the Diversified Category.

\section{Group II: Industries reporting on corporate governance practices after the regulatory norms imposed}

This group consists of companies from those various industries, with a good number, which reported on the corporate governance practices in their annual reports in some or the other form. Many of them have employed their self-sustained principles of corporate governance to some extent. However, some of them have also adhered to the norms of the corporate governance practices through a gradual change, which has come over after realizing the necessities of the various committee reports and recommendations for effective implementation of the structures of governance. They are from Automobiles, Consumer Durables, Telecom, Chemicals, Pharmaceuticals, Real Estates, Iron and steel, Computer Software and Office Equipments, Fast Moving Consumer Goods, and Oil \& Gas, Paints and the Diversified Category to name a few.

\section{Group III: Industries reporting with an ephemeral reference on corporate governance practices}

This group consists of companies from those various industries which provided only an ephemeral reference on the corporate governance practices during the period of study. They seem to have no impact of the rules and regulation framed to adopt such principles in order to pave the way for a scam free environment. They are mainly from Automobiles, Computer software, Oil \& Gas, Pharmaceuticals and Iron \& steel Industries.

In the present study, the formidable changes in the practice of the corporate governance reporting have been revealed as follows:

- By the end of 2015-16 all the 10 categories of industries with a total of 50 companies have already started reporting on the aspect corporate governance in some or the other form in their annual reports.

- This gradual change took place because of the effect of the committee reports submitted to SEBI, firstly by Kumar Mangalam Birla in 2000 followed by its implementation in clause 49 of the listing agreement of SEBI. In pursuant to the revision of the clause 49, another committee report by N.R. Narayana Murthy was submitted in Feb. 8, 2003. On the basis of the recommendations of the 
committee, the standards of corporate reporting were thought to be raised through proper implementation of the norms of governance, i.e. by SEBI. Again, clause 49 was revised for proper implementation in Aug. 26, 2003. SEBI then started requiring for the corporate governance reporting as a mandatory requirement again by replacing the existing clause 49 in Oct. 28, 2004. However, the compulsory compliance was made to be effective from Jan. 1, 2006.

- From the Table 1, it becomes clear that initially only a few companies, i.e. 20 out of 50 have started implementing reporting principles of the corporate governance since the compliance has been felt to their advantage unleashed entirely depending upon their ability to identify the opportunities affecting the long-term affluence of the companies.

\section{Findings}

The following testing conclusions have been drawn from the above investigation.

(i) During the period of study, the implementation of the corporate governance reports in the companies annual reports have been predominantly followed in most of the companies irrespective of their nature, size and age. However, the pattern and timing of implementation have been different in various industry groups and especially those companies which outperform, irrespective of their size and age. They have been making earnest commitment to enhance their own philanthropy through their enormous contribution to the society. It is essentially for gaining respect, developed as a strong force not only in the local market, but also in a rapidly globalizing economy, for building up the global competencies lingering pertinently, over time and geographies. The investors, no longer remain contented with featureless accounting figures but with the updated vision of the strategic management, and the innovative force of the company. This enviable awareness has gradually aroused through time among the corporate and the industry groups that could promote the market competition along with the other complimentary factors to good corporate governance.

(ii) In the same period, it also becomes evident that, there has been significant difference in the method of reporting on corporate governance among the various companies of the industry groups. Although there have been steady rise in the awareness of the significance of the endurance of good governance and its statutory compliance from 2013 to 2016, yet the means of achieving it did not produce the desired results to greater extent. The companies or the industry groups in the pursuit of the same conducive, efficient and effective governance mechanism of the reforms process have understood this to be giving the qualitative improvement of corporate long-term objectives. This accomplishment is based on a code of good corporate practices and meaningful disclosures with a high degree of transparency and fair dealings.

From the above analysis, it is also observed that during the period of study, even though there have been corporate governance reporting of 50 listed companies out of the 10 industry groups, there have been variations in the manner of reporting among the various companies. In other words, 5(14.29\%) industries comprising of 25 companies did not exhibit any proper compliance through reporting in their annual reports and only a passing reference on the subject have been made (Table 1). However, the remaining 5 industries, comprising of 25 companies have been found to be reporting on corporate governance as per clause 49 in the listing agreement of the SEBI Act.

\section{Conclusion}

The Indian environment of which the companies are microcosm is changing at a very faster rate and to manage this change, good business sense is evolving as the unique solution. This is being done by using the substratum principles of international corporate governance. Companies, to some extent have been trying in inculcating an ethnicity of transparency and accountability. This permeates the whole organization and a sacrosanct code of business ethics is to be woven into the very structure of the company. In the study, it has been observed that that implementation of the corporate governance principles in the system and their reporting in the annual reports has been gradually and slowly incarnated into the corporate conscience to exude transparency, openness and accountability. The process has been slow but progressively budding from the year 2013-14 to 2015-16 in the Indian industries. As observed, some companies have developed capabilities in identifying and translating the opportunities into reality, infused the public with a vision sparking dynamism and entrepreneurship, created a system of succession, combined stability with flexibility and continuity to become robust engines and responsible corporations. 


\section{References}

[1] Changanti, R.S. Mahajan, V., \& Sharma, S. (1985). "Corporate board size, composition and corporate failure in the retailing industry". Journal of Management Studies, Vol-22, 400-417.

[2] Daily, C.M. and Dalton, D.R. (1997) Separate but not Independent: Bard Leadership Structure in Large Corporations. Corporate Governance: An International Review, 5(3), PP. 126-136.

[3] Daily, C.M. \& Dalton, D.R. (1993). "Board of directors, leadership and structure control and performance implications" Entrepreneurship Theory and Practice, 17(3), 65-81.

[4] Murugensan Selvam, John Raja, Arumungan Suresh Kumar (2006) "Corporate Governance and Performance_Indian Banking System" Working paper.

[5] Pfeffer, J. and Fong, C. (2002). The end of business schools? Less success than meets the eye, Academy of Management Learning and Education, Vol. 1 No. 1, pp. 78-95.

[6] Rafel, Miguel, and Vicente, 2004, "Governance Mechanisms in Spanish Banks. Does ownership Matter?", Journal of Banking and Finance, 2311-2330.

[7] Schwartz, P and B. Gibb. 1999. " When Good Companies Do Bad Things Responsibility and risk in an age of globalization". New York: John Wiley \& Sons.

[8] Singh, A. (2003) "Corporate Governance, Corporate Finance and Stock Markets in Emerging Countries" Working Paper No. 258, ESRC Centre for Business Research, University of Cambridge, UK.

[9] Aktaruddin, M. Hussain, M.A. Hussain, M and yao Lee (2009). Corporate Governance and voluntary disclosure in corporate annual reports of Malaysian Listed firm. The Journal of Applied Management Accounting Research, Vol. -7 No - 1, 2009.

[10] Swami, P. (2005) "India's highest paid executives". Business India. November $7^{\text {th }}$

[11] Kumar Mangalam Birla Committee Report on Corporate Governance, 2000.

[12] N.R. Narayana Murthy Committee Report on Corporate Governance, 2003

[13] Revised Clause 49, Listing Agreement, SEBI, 2003 and 2011.

[14] http://web.sebi.gov.in/commerceport/clause49.html.

[15] www.ssrn.com

[16] www.oecd.org 